\title{
A Multi-Criteria Decision for Touristic Revitalization of Historic Waterfront Based on AHP Analysis: A Case Study of Ezbet El-Borg City, Damietta, Egypt
}

\author{
Ghada A. Ragheb ${ }^{1 *}$, Amany Ragheb ${ }^{2}$ \\ ${ }^{1}$ Architecture Department, Faculty of Engineering, Pharos University, Alexandria 21311, Egypt \\ ${ }^{2}$ Architecture Department, Faculty of Engineering, Delta University for Science and Technology, Gamasa 11152, Mansoura, \\ Egypt
}

Corresponding Author Email: ghada.ragheb@pua.edu.eg

https://doi.org/10.18280/ijsdp.160804

Received: 18 September 2021

Accepted: 17 November 2021

\section{Keywords:}

analytic hierarchy process, multi-criteria decision making, sustainable development, urban waterfront, waterfront Revitalization

\begin{abstract}
This research finds an approach to support multi-criteria decision-making about the touristic revitalization of the waterfront for the purpose of conservation and sustainable development. The waterfront revitalization strategy is an effective way to preserve the neglected heritage, enhance identity and authenticity, and improve the quality of life. This paper presents a systematic multi-criteria approach and an analytical method in decision-making to revitalize the waterfront of Ezbet El-Borg city, Damietta, Egypt. The waterfront was analyzed according to the criteria of sustainable revitalization. The AHP method was used as an analytical tool to prioritize these criteria to make them measurable, and then suggest an effective strategy for revitalization through the prioritizing alternatives to waterfront functions then used to rank the best prospects for revitalization. The study found the most successful option is to revitalize the historic waterfront of Ezbet El Borg, due to its heritage features. This kind of revitalization plays an essential role in sustainability, as it enhances the city's identity, conservation opportunities, economic development, and quality of life. Applying this approach allows policymakers to develop strategies for waterfront revitalization, and to evaluate the best solutions for the revitalization process with regard to preservation and sustainable development.
\end{abstract}

\section{INTRODUCTION}

Waterfronts are an area integrating the needs of the population and city, and attract human activities, where urban development and water interact $[1,2]$. Over time, the shape of cities has changed dramatically worldwide. Many economic, social and environmental problems have happened in developing waterfronts [3]. Various industries and activities have given way. The economic situation was exacerbated by the speed of development [4], and those old areas became deserted, devoid of activities and people [5]. Socially, many cultural buildings - old and historical places on the waterfront have been neglected due to rapid urban development [6]. The community and tourists did not interact with old buildings, culture, local heritage, and the environment. These increased crime rates led to an unhealthy social lifestyle and isolated neighborhoods from each other [7]. Environmentally, the waterfront has lost its old values and identity and has become less appealing to tourists and locals [8]. In addition to resource scarcity, global climate change, and sea-level rise. From the above, decision-makers and planners face several challenges in developing the urban waterfront and finding mechanisms and solutions for a sustainable future to achieve new needs. This call for finding new tools to achieve a sustainable revitalization strategy to improve the social, environmental, and economic conditions of the waterfront through the revitalization of communities and public spaces [9]. Waterfront revitalization can play an important role in tourist attractions by creating a strong relationship between tourist sites and place values [10]. According to UNESCO, there are two approaches to tourist attractions: natural (areas of scientific, physical, biological, geological, or aesthetic value), and cultural (group of buildings, historical or aesthetic site, archaeological or scientific values) [11].

\subsection{Waterfront revitalization}

Waterfront revitalization is considered one of the important topics in the world of planning theory [10]. Industry and the strength of the economy have occupied a distinguished place within the waterfront since the Industrial Revolution, and have declined over the decades. In the late fifties and sixties of the twentieth century, the need for waterfront revitalization strategies began, but they were small in size and represented in the reuse of buildings. Developers are currently collaborating on different practices and ideas to revitalize the waterfront by offering new possibilities for human access and multiple activities to exploit the natural and cultural potential. The idea of revitalizing the waterfront has combined with the movement of heritage preservation and urban revitalization when historical buildings are located on the water [12]. The legislation directed to salvage these buildings prompted several waterfront revitalizations to include recreational areas, jogging, and cycling paths along the facade. As well as finding recreational activities such as boats and fishing, many waterfront projects include piers and boat slides. 
Tourism, as an element to attract attention, plays an important role in revitalizing many waterfronts and achieving economic gains. Early waterfront projects were intended to attract tourism to the city. Now, the waterfront is closely linked to redevelopment strategies in general, serving as best practices for non-waterfront topics such as urban redevelopment and design [12].

It can be used the revitalization strategy in different kinds of waterfronts. Waterfronts are classified on the basis of functions into six models [2]: 1. Commercial waterfront encourages the public to enjoy the public enjoyment of the waterfront through work, shopping, social communication, and entertainment. 2. The educational and cultural waterfront including cultural places, environmental parks, and public art buildings. 3. Historic waterfront that works for a richer approach through the conservation and adaptive reuse of historic buildings and areas 4 . The recreational waterfront provides a pleasant space of parks, walkways, marinas, fishing areas, play, and meditation areas. 5.The residential waterfront, which provides urban projects. 6 . Working waterfront, which shows the continuous industrial uses of the waterfront in the city center.

\subsection{Multi-criteria decision making waterfront}

The views of participants in decision-making vary, depending on many factors. It is preferable to use specific methods of processing and evaluating the decision-making process [13]. There is no clear tool to support the decision to revitalize the waterfront to assess and identify the special capabilities of preserving heritage, preserving neglected sites, inspiring identity and authenticity, and attracting tourists. In this respect, this research attentions on city of Ezbet El-Borg in Damietta, Egypt. The research recommends a multi-criteria approach to developing a decision-support tool in waterfront revitalization. This is done by studying and analyzing the type of waterfront according to the criteria of sustainable revitalization. And determining the features that have the greatest potential to preserve the heritage and attract tourists. Then it was adopted in revitalizing the sustainable waterfront for the city of Ezbet El-Borg and validating it using the AHP method. To suggest an effective revitalization strategy, the AHP method was used to prioritize and measure revitalization criteria. By prioritizing alternatives to waterfront types, their use can be adopted for the best revitalization potential. Applying this tool enables policy makers, and specialists to assess and measure restored waterfronts regarding functions and abilities for heritage preservation and tourism attraction and then decide.

\section{METHODOLOGICAL FRAMEWORK}

The research was conducted on the basis of a feasibility study (decision game) to revitalize the waterfront of the city of Ezbet El Borg for tourism with the aim of protection and sustainable development using the hierarchical structure in the Analytical Hierarchy Process (AHP). A comparison of standards and their alternatives is made using the pairwise comparison matrix. Each matrix must be reciprocal and positive. A literature review of previous studies of waterfront revitalization was analyzed using a defined set of keywords; It included waterfront revitalization, urban waterfront, sustainable development, the analytic hierarchy process, and multi-criteria decision-making. Databases available from
ScienceDirect, Google Scholar, Scopus, Taylor, Francis, and Sage were used to access articles and references needed to search from highly-rated journals. Including cities, sustainable operations management, sustainable development and planning, sustainability, social and behavioral sciences, Habitat International, and conference papers.

\subsection{Sustainable development of the urban waterfront}

The renewal of the waterfront is one of the important starting points for the renewal of the city itself and its placement in the worldwide context. According to the key elements of sustainable coexistence between waterfronts and cities, achieving lasting success in waterfront renovations. And according to the results of the 2000 World Conference in Berlin on (Urban 21) and in the context of EXPO 2000. There are 10 principles for the sustainable development of urban waterfront areas that are identified: "The quality of water and environment, waterfronts are part of the existing urban fabric, The historic identity gives character, mixed-use is a priority, public access is a prerequisite, public participation is an element of sustainability, Planning in public-private partnership speeds the process, waterfronts are long-term projects, waterfront profit from international networking, revitalization is an ongoing process"[14, 15]. To ensure impartiality, previous studies were reviewed for the advantages of waterfront revitalization to attract tourism through its relationship with different types of waterfront grouped based on three basic sustainability criteria (social, environmental, and economic) [16]. The list identified and developed as shown in Table 1 .

\subsection{Analytic hierarchy process (AHP)}

The AHP method can be applied to assist decision-makers in the decision support process. The problem is divided into a multi-level hierarchical system of goals, standards, and potentials Figure 1 [17]. By relying on AHP pairwise comparisons across many levels of the hierarchy, the relative value of variables is measured. The best alternative is chosen from the default alternatives after comparing them at the last step of the hierarchy. Decision criteria are organized hierarchically into sub-criteria so that the AHP can help solve the problem and perform its role effectively in supporting decision-making [18]. Considering the rating measure (Table 2) advanced (1980) by Saaty, the priority evaluation mechanism to explain the relative importance of the criteria is achieved by establishing a numerical assessment for each criterion. Pairwise comparisons of these criteria give matrices to calculate their value $[19,20]$.

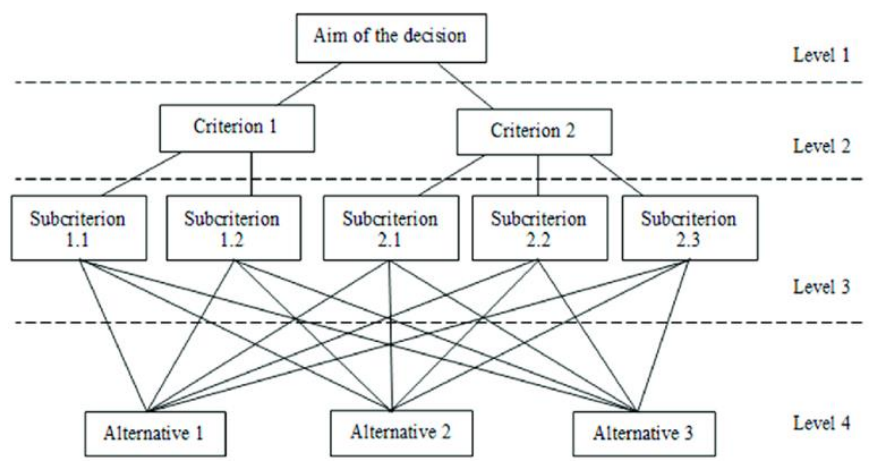

Figure 1. Hierarchical structure in (AHP) process [21] 
Table 1. The advantages of waterfront revitalization to protect heritage and attract tourism

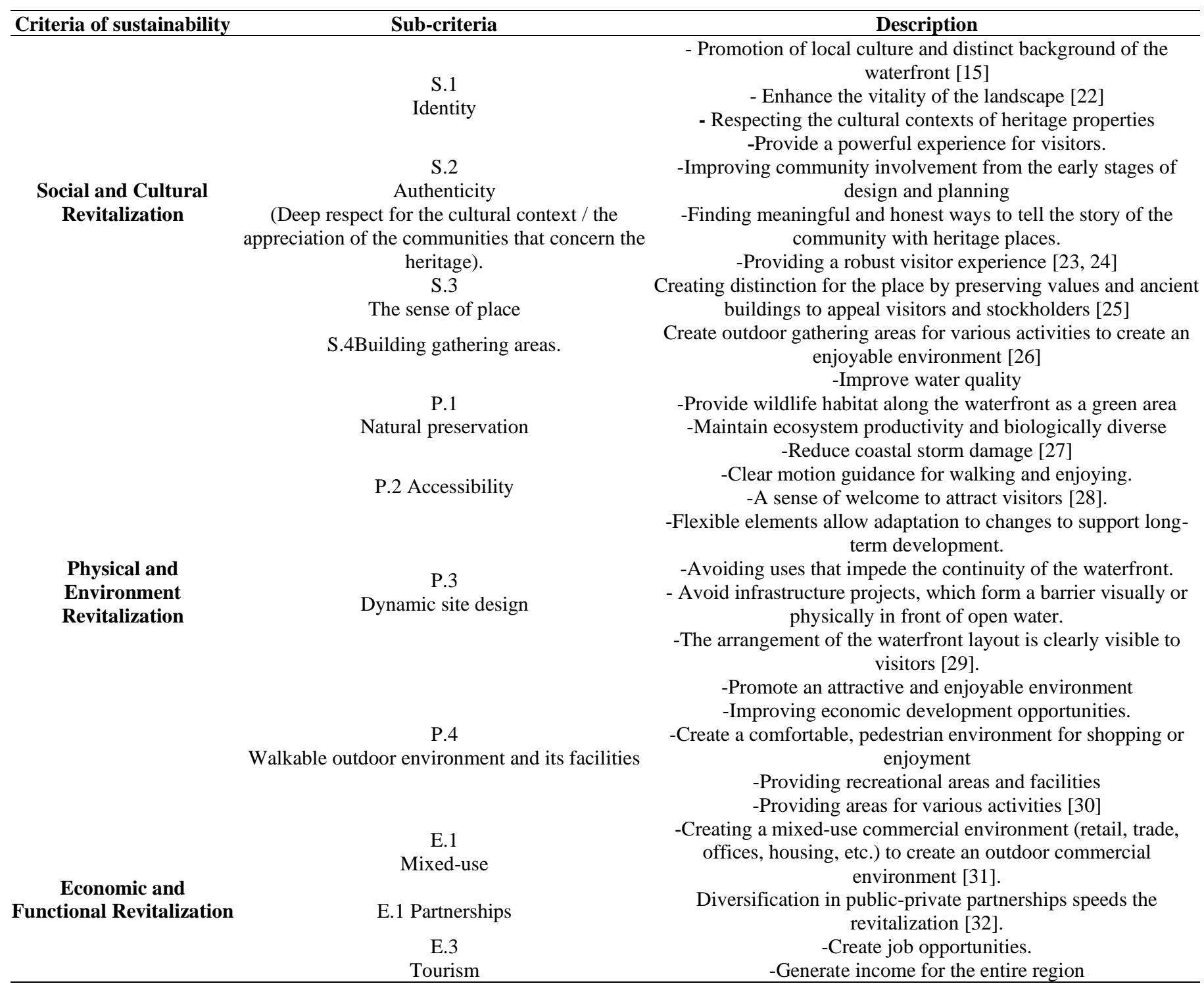

Table 2. Pairwise comparison scale of Saaty [21]

\begin{tabular}{|c|c|c|}
\hline Strength of rank & Classification & Description \\
\hline 1 & Equal in rank & Two conditions are of equal importance in reaching the goal. \\
\hline 3 & Feeble value of one over another & Depending on experience and judging, one standard is supported on the other. \\
\hline 5 & major value & Depending on experience and judging, one criterion is strongly supported. \\
\hline 7 & Demonstrated value & The domination of one standard over the other \\
\hline 9 & Extreme value & The high thought arrangement when one criterion is more significant than another. \\
\hline $2,4,6,8$ & Average values & between the two related judgments, if there is a compromisation. \\
\hline $\begin{array}{c}\text { Reciprocals } \\
1 / 3,1 / 5,1 / 7,1 / 9\end{array}$ & When comparing two $\mathrm{cr}$ & riteria, there is a mutual value if there is a number listed above dedicated. \\
\hline
\end{tabular}

\section{CASE STUDY: EZBET EL-BORG, DAMIETTA, EGYPT}

At the mouth of the Damietta River, one of two Nile's branches the, Ezbet El-Borg is located on the northern coast of Egypt, at the end of the Nile opposite Ras El-Bar, about $15 \mathrm{~km}$ north of the city of Damietta, on the eastern bank of the Nile at its mouth in the Mediterranean Sea, about $210 \mathrm{~km}$ north of Cairo, and it follows the center of Damietta Figure 2 [33]. Surrounded by water, wetlands, meadows, landscapes, and an expansive horizon, many attractive landscapes. The city is distinguished by its attractive archaeological richness, historical sites, and cultural elements. The city's name refers to the defensive tower, and its minaret was built in 1869 to guide ships into the Mediterranean sea 180 feet high [34].

When considering the local background and culture of Ezbet El-Borg and the distinctive identity of the city and the waterfront, Ezbet El-Borg has many undiscovered natural and archaeological abilities.

Its location is the meeting point of the three aquatic systems: Mediterranean, River Nile, Manzala lake, and wetland Figure 3 . The tongue area is the area where the eternal Nile meets the Mediterranean Sea. it is a concrete barrier that was built on the northeastern coast of Ras El Bar resort in 1938. It provides an 
opportunity to enjoy the wonderful panoramic views of Ras El Bar and Ezbet El Borg's “The Fishermen's City" where it can be used for visitors to enjoy the sight of the waves breaking on the concrete barrier and the flying mist of seawater, especially during sunset time.

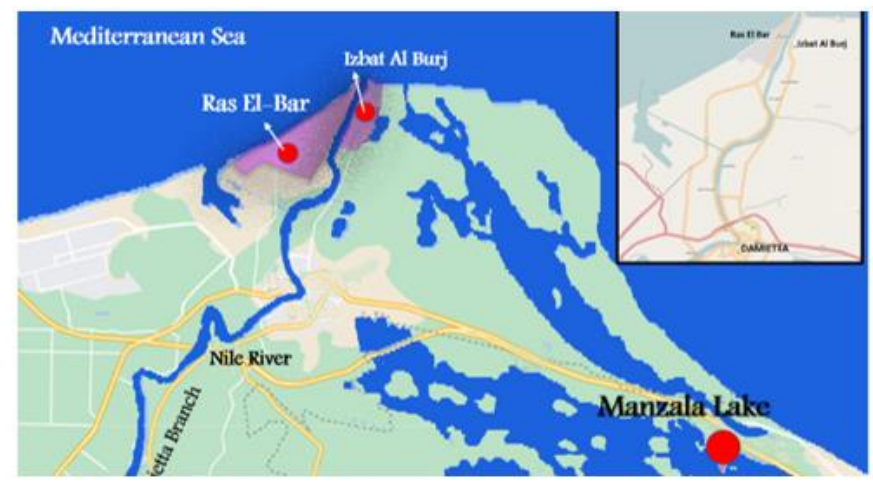

Figure 2. The geographical location of the Ezbet El-Borg

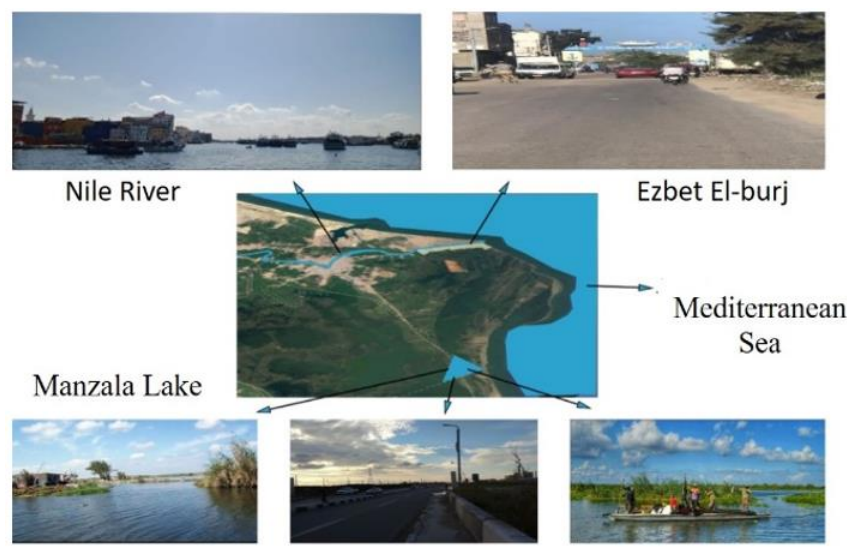

Figure 3. Ezbet El-Borg location

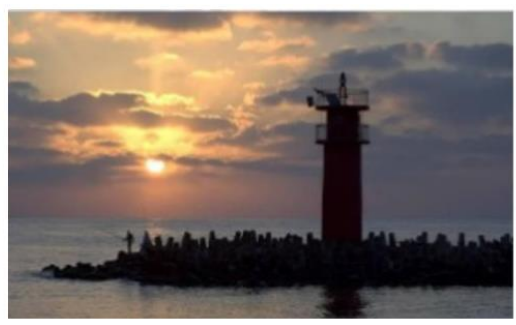

a) Lighthouse of Ezbet El-Borg
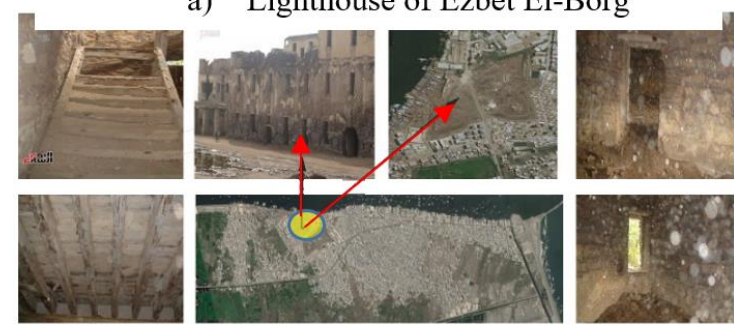

b) Tabia Orabi, Ezbet El-Borg.

Figure 4. Archaeological sites in Ezbet El-Borg (the lighthouse and Tabia Orabi

The area is rich in various waterfront attractions, characterized by relative proximity in a fascinating natural and cultural context. It contains several archaeological sites (the lighthouse of Ezbet El-Borg, Tabia Orabi, and the old shipyard) of exceptional beauty Figure 4(a,b), unexplored, with limited access, and not included in development plans for developing tourism [35]. It also includes the Edfina factory for the manufacture and canning of fish and the oldest shipmanufacturing arsenal. The market of tourism is concerned with this kind of natural and archaeological heritage. This attractive archaeological heritage, sites and other elements related to cultural tourism can be used for tourism development in meaningful and honest ways. Opening such sites to the public and providing a robust experience for the visitors makes these parts of the waterfront attractive for tourism.

The population of Ezbet El-Borg is approximately 100,000 people, most of whom work in the fishing profession and the consequent other industries such as the manufacture of boats, selling fish, selling nets and fishing supplies, and there is a department for selling fish as well as several workshops for the manufacture of fishing vessels, yachts, and boats Figure 5. Ezbet El-Borg city has the oldest ship-manufacturing arsenal in Egypt and about two-thirds of the Egyptian fishing fleet. due to the work of most city's residents in the profession of ship manufacturing, and then fishing, the profession of shipmanufacturing is a historic profession, especially since the manufacturing process is still manual in the city. The arsenal dates back to 1905 when it started manufacturing ships and boats with sails to connect Egypt, Sudan, and Europe until the emergence of engines, and the export phase began in 1948 to neighboring countries. So, the arsenal carved its place in the Egyptian economy. Damietta Governorate includes about 40 thousand fishermen, most of whom are stationed in Ezbet ElBorg city in Damietta [36].

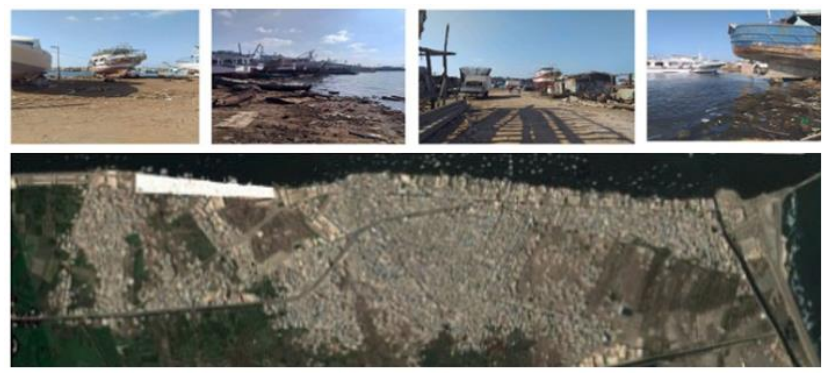

Figure 5. Fishing boat manufacturing sites in Ezbet El-Borg

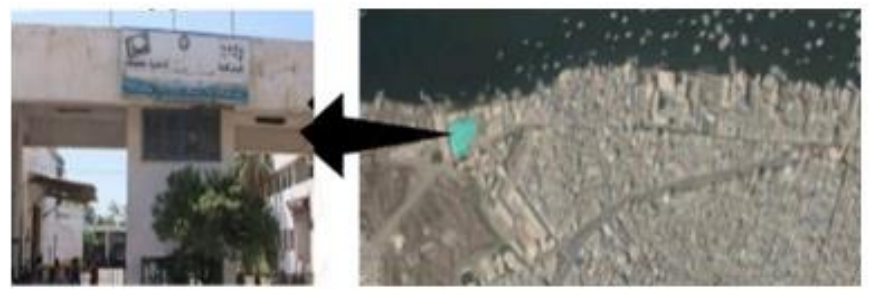

Figure 6. Edfena factory which located in Ezbet El-Borg in since 1960

The Edfena factory has been located in Ezbet El-Borg in Damietta since its establishment in 1960 Figure 6. Its aim was to benefit from the city of Ezbet El-Borg, which has the largest fishing fleet in Egypt, where it uses fish caught from the Mediterranean Sea, processed, packaged, and sold. The area of factory is about 11 thousand square meters, on which there are three factories for the production of fish powder; an ice factory, and another for the production and packing of fish. The factory has been deteriorating and has been out of 
production for years, and the modernization of its machines, with no lines having been updated since its inception in the 1960s, has been neglected. There are of great importance to enhance the utilization of the factory, developing production lines, improving the conditions of workers, and raise their efficiency, and benefit from the distinguished brand for them, and their long history in the Egyptian and foreign markets. in addition to their growing role in light of the growth of the Egyptian market and the increase in the number of consumers.

Ezbet El-Borg is a small and quiet town that lacks an active social life, and tourists live in Ras El Bar-facing it only during the summer. Tourism and related services are not one of the most important sectors of the El Borg manor's economy, through which a major income can be provided to residents. Ezbet El-Borg contains the potential for several tourist activities in different destinations, which makes it unique. The beach tourism will remain the main power for developing tourism. There is a need along the coast of Ezbet El-Borg to build some hotels and tourist villages while preserving the character and landscape.

The economic growth in the region led to changes in the social structure and increased demand for building. There has been a noticeable increase in informal construction due to development after the 1990 s without considering the urban planning and surveying. Informal construction and cement beaches pose a direct hazard to the environmental prservation and sustainable progress of the waterfront. In addition to the narrowness of some streets that are not qualified to walk. In this context, the city of Ezbet El-Borg must develop new local planning tools for its own development. Waterfront planning enables sustainable, controlled, and directed territory development to ensure a healthy environment for today and future generations. Ezbet El-Borg, with its livestock and farming that has been developed, presents excellent opportunities for developing agritourism. Through the analysis of the case Ezbet El-Borg city according to the list of the advantages of waterfront revitalization to protect the heritage and attract tourism, a structured approach is obtained to evaluate and support decision-making in the acceptable fit between multiple fields [28-31]. This is to achieve protection decisions and procedures and define strategy [18].

\subsection{The AHP model}

This manuscript sets out an approach to revitalize a historical waterfront for tourism in the case of the Ezbet ElBorg city, with the purpose of preservation and sustainable development. Starting from the analysis of the ancient city according to the list of the factors of waterfront revitalization. the collected data were through a survey form from specialists, planners, academics, and heritage preservation administrators. The discussion of responses and their organization into meaningful groups was revised to fit the use of AHP analysis.

Then, classifying these various factors through an AHP template was formed. This categorization was decided based on their abilities for achieving successful protection and sustainable development strategies. Regarding potential effective intervention targets, they are arranged from the best to the worst. The revitalization criteria can be outlined as follows Tables 3, 4, 5 .

All six waterfront types previously referred to in the introduction were involved in the formation of the AHP model. They are considered the six alternatives for decision-making. Through the AHP program, the waterfront alternative with the greatest potential for tourism will be indicated relative to the case of Ezbet El-Borg.

Priorities for revitalizing the waterfront of Ezbet El Borg are determined using the AHP program. Once the problem has been clarified and built the hierarchy, the relative importance of the criteria begins to be determined to the prioritization. A two-way comparison of criteria is made depending on their levels. Pairwise comparisons were made on an eleven-level standard comparison scale [37]. Through the structured assessment of sustainable waterfront Revitalization criteria and harmonization of their severity using AHP, is produce a measurable quantity of the value of each criterion in decision process [38].

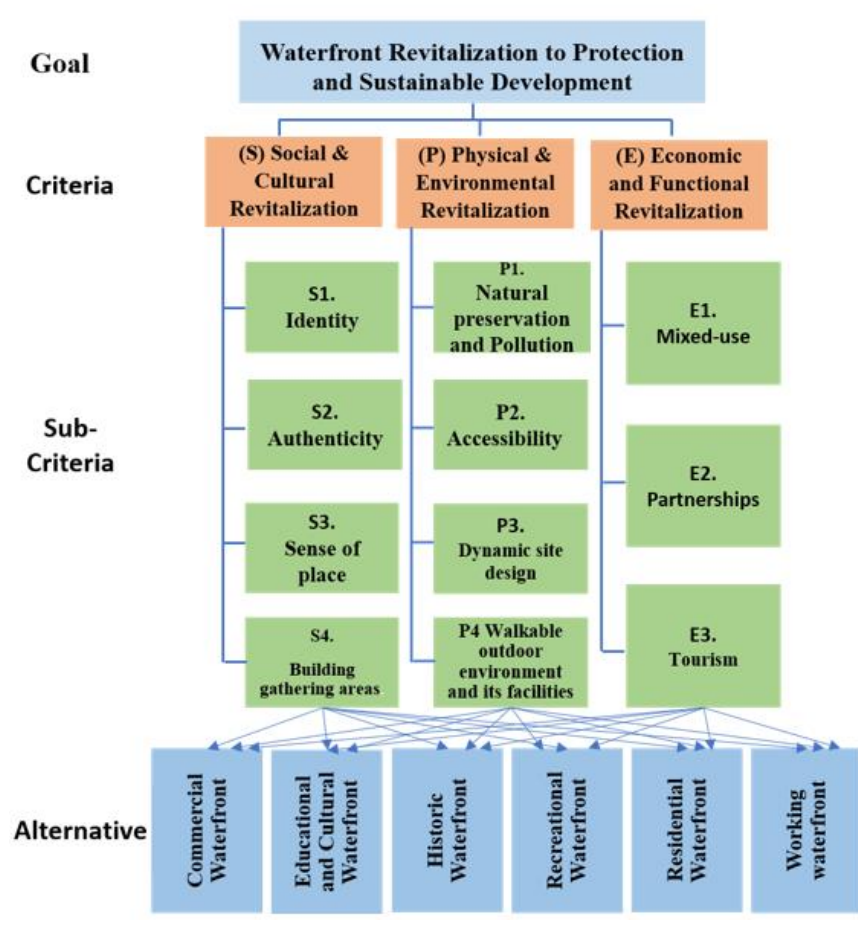

Figure 7. Building of the Hierarchical decision problem by (AHP) method

The idea of using AHP's work is to systematically assess and make measurable criteria for sustainable waterfront revitalization [39]. According to the six types of interface functions, different plans can be recognized [40]. By making pairwise comparisons of revitalization criteria and analyzing them across the AHP, and additional values can be achieved. With the help of AHP, decisions are analyzed and supported to be applied correctly, through the framework of sustainable revitalization criteria as a basis for analysis. The values necessary to support decision-making are reached after making pairwise comparisons between the criteria. The AHP method [41], as shown in Figure 1, continues as follows:

1. The decision problem is defined and the information required from the criteria of the sustainable revitalization of the waterfront is defined from previous studies [42].

2. A hierarchical structure that contains the main objective was set up, criteria and sub-criteria, and alternatives Figure 7.

3. Comparisons are made between pairwise sustainable revitalization criteria as to which of the two comparison criteria is most important. So, the switch of significances for these parameters is considered [43].

4. Mutual values of the sets of revitalization criteria are 
determined.

5. Strategy alternatives are evaluated with respect to each criterion for sustainable revitalization.

6. To reach the optimal solution to the decision problem, the priorities of the alternatives are studied according to the general hierarchy [20].

By studying the main factors and their derived numerical values, the targets that help sustainable waterfront revitalization can be identified [38].
The matrices of revitalization have been handled using AHP after determining the coefficients of comparison matrices through a questionnaire of specialists. Table 6 presents the pairwise comparisons which made for the revitalization groups, through the 1-9 Saaty scale. While Tables 7, 8, 9 presents the pairwise comparisons made for the sub-criteria of the revitalization matrices in relation to each of the criteria.

Finally, Table 10 shows the total priority of the activating factors.

Table 3. Social and cultural revitalization for Ezbet El-Borg city

\begin{tabular}{|c|c|}
\hline \multicolumn{2}{|r|}{ Social and Cultural revitalization } \\
\hline $\begin{array}{ccc} & \text { - } & \text { The } \\
\text { S.1 } & \text { - } & \text { Woo } \\
\text { Identity } & \text { - } & \text { pres } \\
& \text { - } & \text { The } \\
\text { S.2 } & \text { - } & \text { The } \\
\text { Authenticity } & \text { - } & \text { A mic } \\
& & \text { herit } \\
\text { S.3 } & \text { - } & \text { The } \\
\text { The sense of place } & \text { - } & \text { Man } \\
\text { S.4 } & \text { Area } \\
\text { Building gathering areas. } & \text { The } \\
\text { urba }\end{array}$ & $\begin{array}{l}\text { esence of a fishing fleet that occupies second place in the Middle east. } \\
\text { en and iron ship industry (the oldest ship-manufacturing arsenal in Egypt). } \\
\text { ce of large fisheries attracts residents of Rashid and Upper Egypt to settle } \\
\text { ty overlooks the meeting point of the Nile River and the Mediterranean Sea } \\
\text { esence of many heritage places such as Orabi Tabia, the ancient marine arsenal, and others, through } \\
\text { a strong experience for the visitor can be activated. } \\
\text { ningful way with the participation of the community can be found to tell about the different stories of the } \\
\text { e places. } \\
\text { esence of areas that can increase the attractiveness of the waterfront by presenting it to the public } \\
\text { archaeological sites are not used to develop tourism and no one knows about them } \\
\text { of exceptional beauty, unexplored, and with limited access. } \\
\text { ck of gathering places due to the increase in random construction without following any principles for } \\
\text { surveying and planning. }\end{array}$ \\
\hline \multicolumn{2}{|r|}{ Table 4. Physical and environmental revitalization for Ezbet El-Borg city } \\
\hline \multicolumn{2}{|r|}{$\begin{array}{l}\text { Physical and Environment Revitalization } \\
\end{array}$} \\
\hline $\begin{array}{l}\text { P.1 } \\
\text { The Natural preservation and } \\
\text { Pollution } \\
\text { P.2 Accessibility }\end{array}$ & $\begin{array}{l}\text { - Low production of agricultural land } \\
\text { - } \quad \text { Swamps and lakes in poor condition } \\
\text { - } \quad \text { Irrigation canals are used to dump city sewage into the sea } \\
\text { - No beaches } \\
\text { - } \quad \text { det using fish resources properly } \\
\text { - } \quad \text { Lack of a healthy environment } \\
\text { - There are excellent opportunities for the development of agricultural tourism } \\
\text { - Unclear motion guidance for walking due to narrow and few main streets and disappearance of } \\
\text { - The sub-streets. } \\
\text { The construction of non-formal and cementitious beaches is a clear threat to the protection of the } \\
\text { - Thvironment and sustainable development of the waterfront. } \\
\text { - } \quad \text { absence of any clear long-term plans to accommodate the various elements for the } \\
\text { Lack of sidewalks, services, various activities and recreational facilities on the waterfront } \\
\text { - } \quad \text { Need to enhance the visual interest in the look of the waterfront, regarding land use, built form, } \\
\text { and landscape treatments. } \\
\text { The possibility of activating the parks for pedestrians with points to observe nature or sighting } \\
\text { paths. } \\
\text { The possibility of creating and improving economic development opportunities along the } \\
\text { interface through the multiplicity of activities. }\end{array}$ \\
\hline
\end{tabular}

Table 5. Economic and functional revitalization for Ezbet El-Borg city

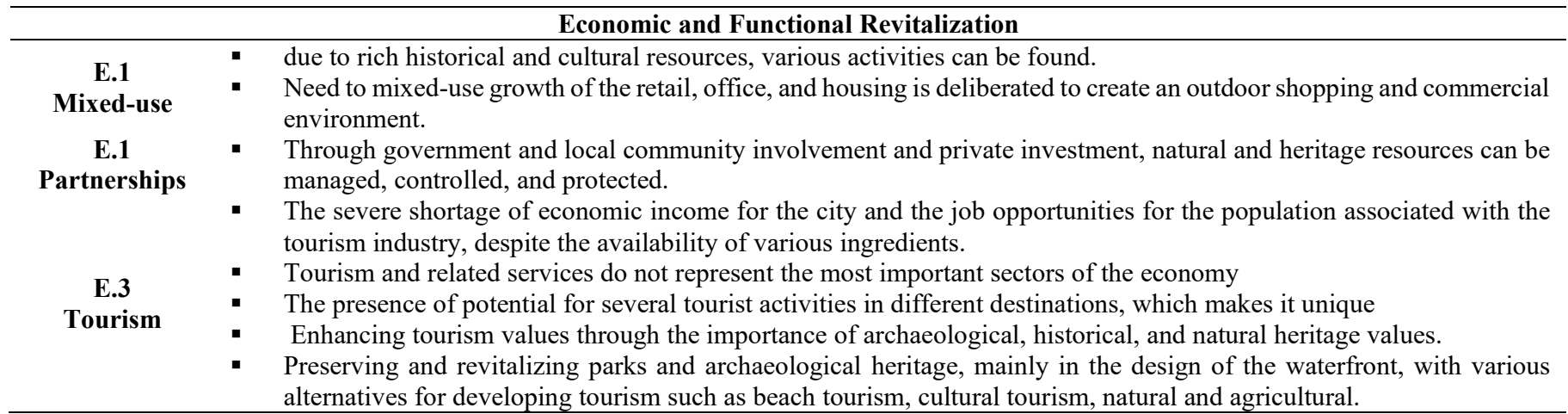


Table 6. Pairwise comparisons model of ustainability criteria "revitalization groups"

\begin{tabular}{|c|c|c|c|c|}
\hline $\begin{array}{c}\text { Sustainability } \\
\text { Criteria }\end{array}$ & $\mathbf{S}$ & $\mathbf{P}$ & $\mathbf{E}$ & $\begin{array}{l}\text { Importance Degrees of } \\
\text { sustainability Criteria }\end{array}$ \\
\hline $\begin{array}{l}\text { Social and Cultural } \\
\text { (S) }\end{array}$ & 1 & 7 & 5 & 0.738 \\
\hline $\begin{array}{c}\text { Physical and } \\
\text { Environmental (P) }\end{array}$ & $1 / 7$ & 1 & 3 & 0.170 \\
\hline $\begin{array}{l}\text { Economic and } \\
\text { Functional (E) }\end{array}$ & $1 / 5$ & $1 / 3$ & 1 & 0.092 \\
\hline
\end{tabular}

Table 7. Pairwise comparison model of the social and cultural criteria

\begin{tabular}{|c|c|c|c|c|c|}
\hline $\begin{array}{l}\text { Social \& Cultural } \\
\text { revitalization }\end{array}$ & S1 & $\mathbf{S 2}$ & $\mathbf{S 3}$ & S4 & $\begin{array}{c}\text { Importance } \\
\text { Degrees }\end{array}$ \\
\hline S.1 Identity & 1 & 3 & 7 & 9 & 0.583 \\
\hline S.2 Authenticity & $1 / 3$ & 1 & 5 & 7 & 0.290 \\
\hline S.3 Sense of place & $1 / 7$ & $1 / 5$ & 1 & 3 & 0.085 \\
\hline $\begin{array}{l}\text { S.4 Building } \\
\text { gathering areas. }\end{array}$ & $1 / 9$ & $1 / 7$ & $1 / 3$ & 1 & 0.042 \\
\hline \multicolumn{6}{|c|}{ Consistency Ratio CR $=6.0 \%$} \\
\hline
\end{tabular}

Table 8. Pairwise comparison model of the physical and Environmental Revitalization Criteria

\begin{tabular}{|c|c|c|}
\hline $\begin{array}{c}\text { Physical \& Environmental } \\
\text { Revitalization }\end{array}$ & P1 P2P3 P4 & $\begin{array}{c}\text { Importance } \\
\text { Degrees }\end{array}$ \\
\hline $\begin{array}{l}\text { P.1 The Natural preservation and } \\
\text { Pollution }\end{array}$ & $\begin{array}{llll}1 & 2 & 3 & 1 / 3\end{array}$ & 0.224 \\
\hline P.2 Accessibility & $1 / 2111 / 5$ & 0.106 \\
\hline P.3 Dynamic site design & $1 / 3111 / 6$ & 0.092 \\
\hline $\begin{array}{l}\text { P.4 Walkable outdoor environment } \\
\text { and its facilities }\end{array}$ & $\begin{array}{cccc}3 & 5 & 6 & 1 \\
\text { Consistency }\end{array}$ & Ratio $\mathrm{CR}=0.9 \%$ \\
\hline
\end{tabular}

Table 9. Pairwise comparison model of the economic and functional revitalization criteria

\begin{tabular}{ccccc}
\hline $\begin{array}{c}\text { Economic and Functional } \\
\text { Revitalization }\end{array}$ & E1 & E2 & E3 & $\begin{array}{c}\text { Importance } \\
\text { Degrees }\end{array}$ \\
\hline E.1 Mixed-use & 1 & 5 & 3 & 0.637 \\
E.2 Partnerships & $1 / 5$ & 1 & 5 & 0.258 \\
E.3 Tourism & $1 / 3$ & $1 / 5$ & 1 & 0.105 \\
Consistency Ratio CR $=54.3 \% \%$ & \\
\hline
\end{tabular}

The results, after using AHP, showed the order of priorities of each of the revitalization groups for Ezbet El Borg: The social and cultural group won the highest percentage (73.8\%) indicating the importance and effectiveness of its role in the success of protection and sustainability strategies; the physical and environmental group ranked second with a percentage of $(17.0 \%)$. While the economic and functional group ranked third $(9.2 \%)$. It is a logical outcome of protection and sustainable development processes where the potential of waterfront revitalization is embodied in historical and cultural waterfronts that act as stimulating elements for economic development. It also encourages people to reconnect with those areas, whether for work, social exchange, residence, or leisure [44]. The fourth column of Table 10 shows the importance of the subcriteria, the Identity with respect to the social and cultural Revitalization has the maximum importance (0.583), followed by the authenticity (0.290), sense of place (0.085), and building gathering areas (0.042), which have lowest rank in relation to other factors.

As expected, the walkable outdoor environment and its facilities are the most important of the physical and environmental revitalization group (0.579). While the rating of accessibility is ranked third (0.106); natural preservation and pollution are more important to consider in ranked second (0.224). The dynamic site design takes the last one (0.092). As well, the top priority for mixed-use is (0.637) for economic and functional revitalization. Whereas partnerships are a medium priority $(0.258)$, while the middle position between them is occupied by the potentials for tourism development (0.105). The above preferences indicate the relative value of the variables revitalization factors in relation to Ezbet El-Borg.

Table 10. Priorities for comparisons for the revitalization criteria and sub-criteria

\begin{tabular}{|c|c|c|c|}
\hline $\begin{array}{l}\text { Revitalization } \\
\text { Groups }\end{array}$ & $\begin{array}{c}\text { Group } \\
\text { Priority }\end{array}$ & Sub criteria & $\begin{array}{l}\text { sub criteria's } \\
\text { priority } \\
\text { within the } \\
\text { group }\end{array}$ \\
\hline \multirow{4}{*}{$\begin{array}{c}\text { (S) Social \& } \\
\text { Cultural } \\
\text { Revitalization }\end{array}$} & \multirow{4}{*}{0.738} & S.1 Identity & 0.583 \\
\hline & & S.2 Authenticity & 0.290 \\
\hline & & S.3 Sense of place & 0.085 \\
\hline & & $\begin{array}{c}\text { S.4 Building gathering } \\
\text { areas. }\end{array}$ & 0.042 \\
\hline \multirow{4}{*}{$\begin{array}{l}\text { (P) Physical \& } \\
\text { Environmental } \\
\text { Revitalization }\end{array}$} & \multirow{4}{*}{0.170} & $\begin{array}{l}\text { P.1 The Natural } \\
\text { preservation and } \\
\text { Pollution }\end{array}$ & 0.224 \\
\hline & & P.2 Accessibility & 0.106 \\
\hline & & $\begin{array}{c}\text { P.3 Dynamic site } \\
\text { design }\end{array}$ & 0.092 \\
\hline & & $\begin{array}{c}\text { P.4 Walkable } \\
\text { outdoor } \\
\text { Environment and its } \\
\text { facilities }\end{array}$ & 0.579 \\
\hline (E) Economic \& & \multirow{3}{*}{0.092} & E.1 Mixed-use & 0.637 \\
\hline Functional & & E. 2 Partnerships & 0.258 \\
\hline Revitalization & & E.3 Tourism & 0.105 \\
\hline
\end{tabular}

The waterfront of Ezbet El Borg can be revitalized by tourism through the priorities of the various functions classified for the waterfronts. According to this study, Tables 11,12 presents priority vectors for the different alternatives to the waterfront functions that can be utilized in arranging the best solutions to revitalize the facade of the Ezbet El Borg.

The tables show determining the pairwise comparison of each criterion with the different types of waterfronts over the decision-making procedure. Then, the calculation of the normalized weight for each criterion, which determines the value of the importance of this criterion. "The normative weight for each criterion was obtained by dividing the sum of all criterion entries in the row by its column sum. The weights are normalized by making the sum of the normalized weighting of criteria equal to 1 "[45]. The study found that the most successful option was to revitalize the historic waterfront of Ezbet El-Borg, where it got the highest weight (0.25), according to the evaluation of the sub-criteria into each model. Where this type of waterfront, if revitalized, can contribute a great deal to attracting tourism compared to other types of waterfronts. Ancient waterfronts work as stimulating factors for economic development. It invites people to reconnect with it with various cultural and recreational activities related to tourism, whether for work, social exchange, accommodation, or entertainment [46]. This type of waterfront is considered a magnet for tourism due to its great cultural and economic values [44]. This helps to enhance the city's identity and economic development, which leads to the sustainability of the 
city as a whole [47]. The second alternative was the revitalization of the waterfront recreational $(0.23)$ because of its natural and environmental components that can be used in tourism development. Then, the educational and cultural waterfront got (0.19), and the residential waterfront came in the last place with a weight of (0.05).

\subsection{The optimum strategy for protection and sustainable development}

According to the approach presented in the research, all requirements and needs should be considered comprehensively, especially in the priority criteria and subcriteria. To achieve the goals of revitalizing the waterfront of Ezbet El-Borg for the purpose of protection and sustainable development, through the research, effective strategies that fit the criteria with cooperation from all stakeholders were proposed. The terms of this strategy could be suggested according to the information obtained from calculating factor priorities through AHP Figure 8 (which changes according to each case study.

It was found from the research that the case of the Ezbet ElBorg needs support for several factors which achieve lowranked by AHP. According to Social and Cultural Revitalization, there is a lack of building gathering areas (S4) where the lowest weight is obtained (0.042). Depending on the waterfront revitalization guidelines, outdoor gathering and connection areas such as parks, platforms, restaurants, gardens, and walkways can be created to organize with space functions and meet the needs of people with great panoramic views. The spaces associated with the various activities of youth should also be developed and commercial spaces for shoppingorganized Figure 9.

This research is also recommended to enhance the sense of place (S3) where it has gained low weight (0.085), by preserving important historical structures and monuments such as the lighthouse, Tabia Orabi, and old shipyard. And take advantage of modern technologies in various activities to attract tourists in these sites. As well as preserving the identity and characteristics of the street through the development and improvement of the urban fabric. In addition to accommodating the waterfront of various types of activities from traditional and recreational to support the identity of old city Figure 10.

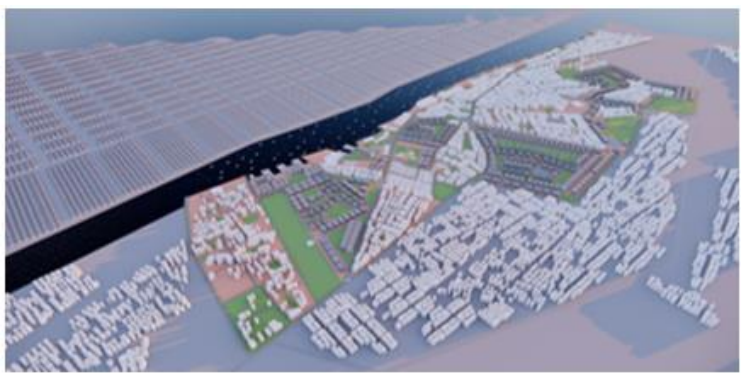

Figure 8. Suggested strategy according to the information obtained from AHP

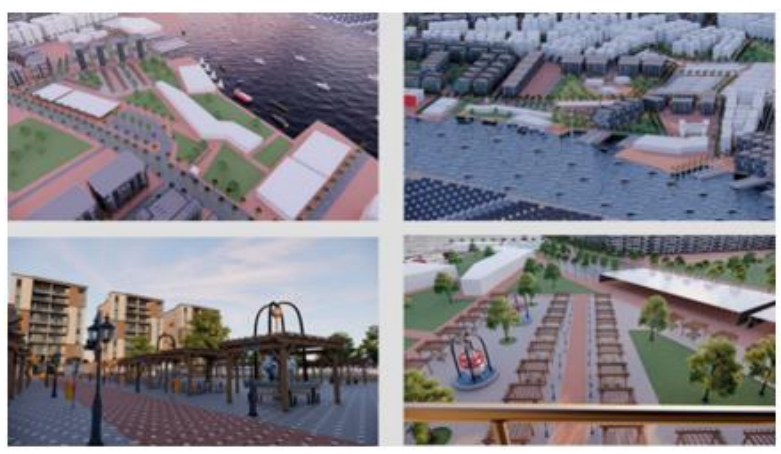

Figure 9. Suggested outdoor gathering and connection areas

Table 11. Normalized alternatives pairwise comparison

\begin{tabular}{|c|c|c|c|c|c|c|c|c|c|c|c|c|}
\hline & \multicolumn{4}{|c|}{$\begin{array}{l}\text { Social \& Cultural } \\
\text { Revitalization }\end{array}$} & \multicolumn{4}{|c|}{$\begin{array}{c}\text { Physical \& Environmental } \\
\text { Revitalization }\end{array}$} & \multicolumn{3}{|c|}{$\begin{array}{c}\text { Economic \& Functional } \\
\text { Revitalization }\end{array}$} & \multirow[t]{2}{*}{ T Av. } \\
\hline & S1 & S2 & S3 & S4 & $\mathrm{P} 1$ & $\mathrm{P} 2$ & P3 & P3 & E1 & E2 & E3 & \\
\hline $\begin{array}{l}\text { Commercial } \\
\text { waterfront }\end{array}$ & 5 & 9 & 5 & 5 & 7 & 5 & 5 & 5 & 5 & 4 & 3 & 585.3 \\
\hline $\begin{array}{c}\text { Educational and } \\
\text { cultural }\end{array}$ & 7 & 7 & 7 & 7 & 3 & 7 & 7 & 7 & 9 & 5 & 5 & 716.5 \\
\hline Historic waterfront & 9 & 9 & 9 & 9 & 5 & 9 & 9 & 9 & 9 & 7 & 9 & 938.5 \\
\hline $\begin{array}{c}\text { Recreational } \\
\text { waterfront }\end{array}$ & 7 & 7 & 7 & 9 & 9 & 9 & 9 & 9 & 9 & 5 & 9 & 898.1 \\
\hline Residential waterfront & 1 & 1 & 1 & 3 & 3 & 3 & 3 & 3 & 1 & 1 & 1 & 211.9 \\
\hline Working waterfront & 5 & 5 & 5 & 5 & 9 & 3 & 3 & 1 & 5 & 3 & 3 & 474.3 \\
\hline Total & 34 & 38 & 34 & 38 & 36 & 36 & 36 & 34 & 38 & 25 & 30 & 26924.5 \\
\hline
\end{tabular}

Table 12. Matrix of weightage for setting the priorities of waterfront types to share in revitalizing the facade of the Ezbet El Borg

\begin{tabular}{|c|c|c|c|c|c|c|c|c|c|c|c|c|}
\hline & \multicolumn{4}{|c|}{$\begin{array}{c}\text { Social \& Cultural } \\
\text { Revitalization }\end{array}$} & \multicolumn{4}{|c|}{$\begin{array}{c}\text { Physical \& Environmental } \\
\text { Revitalization }\end{array}$} & \multicolumn{3}{|c|}{$\begin{array}{c}\text { Economic \& Functional } \\
\text { Revitalization }\end{array}$} & \multirow[t]{2}{*}{ T Av. } \\
\hline & S1 & $\mathrm{S} 2$ & S3 & S4 & P1 & $\mathrm{P} 2$ & P3 & P3 & E1 & E2 & E3 & \\
\hline $\begin{array}{c}\text { Commercial } \\
\text { waterfront }\end{array}$ & 0.1 & 0.2 & 0.1 & 0.1 & 0.2 & 0.1 & 0.1 & 0.1 & 0.1 & 0.2 & 0.1 & 1.70 .15 \\
\hline $\begin{array}{c}\text { Educational and } \\
\text { cultural }\end{array}$ & 0.2 & 0.2 & 0.2 & 0.2 & 0.1 & 0.2 & 0.2 & 0.2 & 0.2 & 0.2 & 0.2 & 2.10 .19 \\
\hline Historic waterfront & 0.3 & 0.2 & 0.3 & 0.2 & 0.1 & 0.3 & 0.3 & 0.3 & 0.2 & 0.3 & 0.3 & 2.70 .25 \\
\hline $\begin{array}{c}\text { Recreational } \\
\text { waterfront }\end{array}$ & 0.2 & 0.2 & 0.2 & 0.2 & 0.3 & 0.3 & 0.3 & 0.3 & 0.2 & 0.2 & 0.3 & 2.60 .23 \\
\hline residential waterfront & 0.0 & 0.0 & 0.0 & 0.1 & 0.1 & 0.1 & 0.1 & 0.1 & 0.0 & 0.0 & 0.0 & 0.60 .05 \\
\hline Working waterfront & 0.1 & 0.1 & 0.1 & 0.1 & 0.3 & 0.1 & 0.1 & 0.0 & 0.1 & 0.1 & 0.1 & 1.40 .12 \\
\hline Total & 1.0 & 1.0 & 1.0 & 1.0 & 1.0 & 1.0 & 1.0 & 1.0 & 1.0 & 1.0 & 1.0 & 11.01 .00 \\
\hline
\end{tabular}



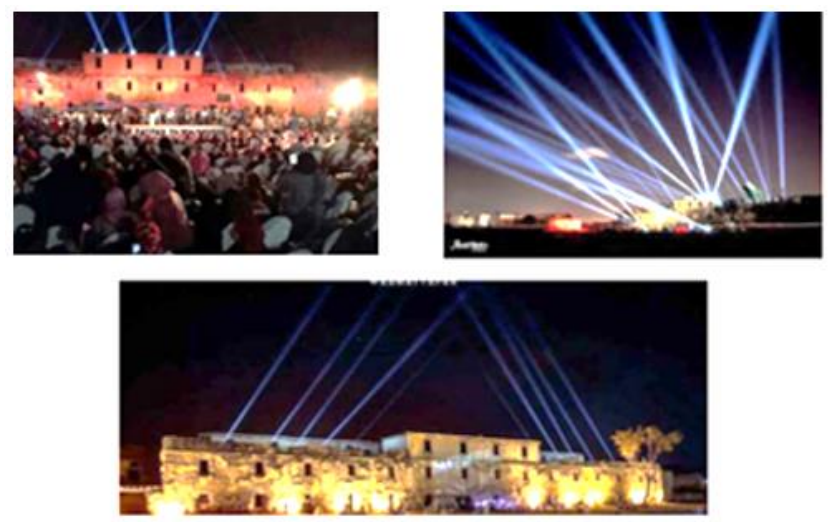

Figure 10. Restoration of Tabia Orabi and its use in tourist activities

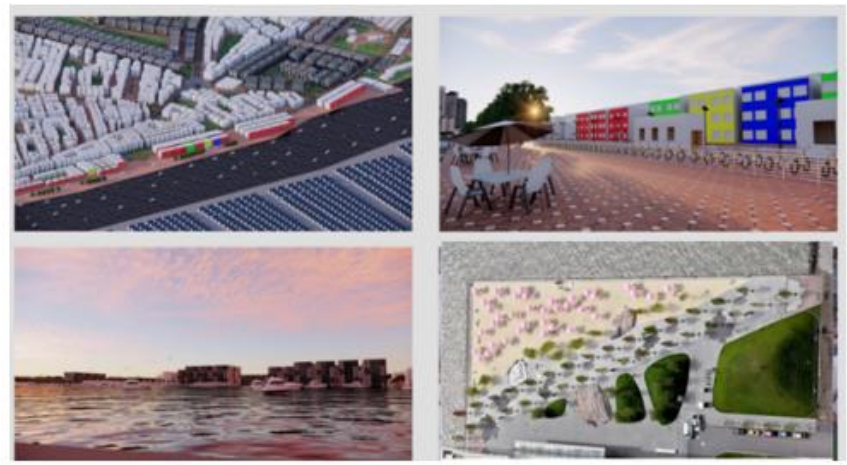

Figure 11. Enhance the visual interest in the waterfront view
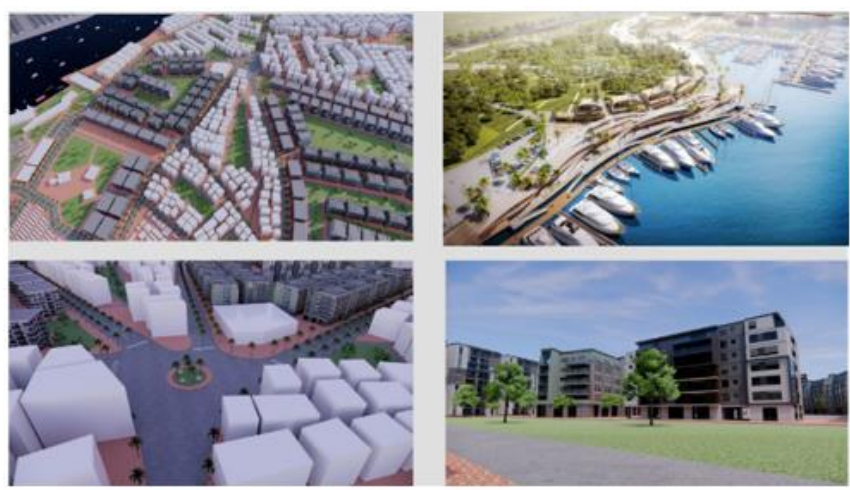

Figure 12. Suggested visual and physical paths
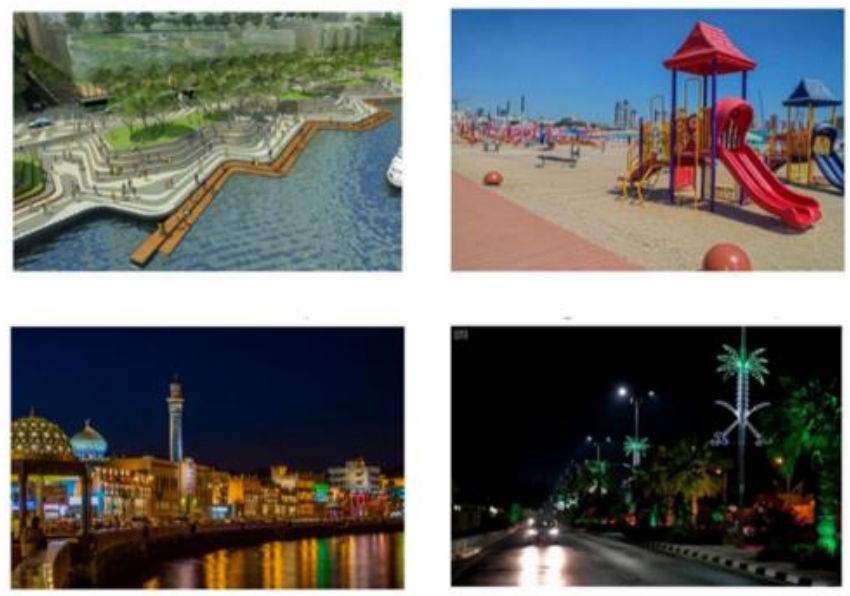

Figure 13. The site should be promoted to the tourism
Recalling identity acts as a major part of attracting visitors to historic waterfronts by preserving ancient buildings and sites while promoting traditional commercial activities, and functional streets and spaces. By creating mixed-use streets, friendly, comfortable, and safe facilities along the waterfront, authenticity can be generated. Which encourages residents and visitors to explore the area and promote social contact [47]. In order to enhance the authenticity, the permeability of the ancient site can be increased by setting up comprehensive circulation systems and improving the existing ones [48].

Regarding physical and environmental revitalization, the (P.3) dynamic site design has achieved the lowest weight (0.092). Therefore, the facade of Ezbet El-Burj city needs a long-term management plan to accommodate the various elements and features that characterize the city for the sustainability of the waterfront. Additionally, the need to issue laws and regulations to prevent the establishment of unofficial beaches, cement facilities, and any projects that impede vision on the city's waterfront and represent a clear threat to environmental protection and sustainable development. Also, the (P.4) Walkable outdoor environment and its facilities have achieved the highest weight (0.579). So, it must enhance the visual interest in the waterfront view in terms of land use, built forms, and landscape treatments. Parks, footpaths, lookouts, and recreation points should also be supported with visibility. With attention to the waterfront cornice with patterns of sidewalks specially designed to determine the directions and sequence of spaces and green services. Also, provide activity minutes away to encourage walking and to distract from the city's longitudinal expansion Figure 11.

Due to the weight of (P.2) accessibility (0.106), it is proposed to expand the city toward both the seashore and both sides of the Nile on the waterfront. by creating a connection with the archaeological area of the Citadel, Al-Fanar, and the shipyard. Visual and physical paths are created, by opening some axes leading to them. The beach is considered a natural park to stop construction and erosion. It is taken into account to find common green spaces between buildings, whose height should not exceed two to three floors, so as not to obstruct the view of the sea. The river taxi can be used as a means of easy access from Ras El-Bar city to Ezbet El-Borg, instead of the old, dilapidated ferries that lack safety. It is suggested to use pedestrian routes to visit the cultural and heritage area, while minibuses for tourists and bicycles can be used within and around the waterfront area. Small boats can also be used to reach different places more easily and with less time and effort. The marina can also be used to launch tourist trips by water to visit the seaside Figure 12

The pollution factor must be taken into account in the revitalization of the historic waterfront $(0.224)$, along with nature conservation. Pollution can be removed through air circulation and flow as a result of the waterfront absorption of prevailing winds and sea breezes [48]. Land use compatibility, building orientation and height, the distance between buildings, and open spaces must be considered in the historic waterfront revitalization scheme [49].

Tourism (E.3) in economic and functional revitalization gained weight (0.105). The research recommends that the site should be promoted to the tourism industry by encouraging visiting ancient sites and monuments Figure 13. Jobs that serve tourism (such as hotels, restaurants and shopping malls) can be replaced in buildings near the Corniche. Consideration must be given to increasing the economic profits of the community, through the conservation of the historical and 
cultural characteristics of areas and adaptive reuse of buildings. Greater attention should also be given to culturally oriented waterfront activities through the ancient buildings.

As well as mixed uses along the old waterfront play an important role in the economic and social development. Participation between government and private agencies and individuals should be encouraged in the revitalization plan.The involvement of the community, especially residents and beneficiaries, in the early stages of planning and design is an important element for the success of revitalization

\section{CONCLUSIONS}

Recently, waterfront revitalization plans are being adopted as a tool for government and local communities to manage natural resources and heritage, control, and protection. The objective of the revitalization plan is to build up a long-range vision for protection and sustainable development in order to improve the physical, social, economic, and environmental circumstances of the waterfront. As well as transform it into a vibrant place. Revitalization projects improve the quality of life and the environment, increase development opportunities, a powerful community sense of place, and a unique identity for users [50].

The research presents a multi-criteria decision-support approach about waterfront tourism revitalization for the purpose of conservation and sustainable development. Ezbet El-Borg, Damietta, Egypt, was chosen as a case study for the revitalization of waterfronts within the framework of sustainable development.

The AHP method was used, an approach that helps support decision-making processes revitalization criteria were prioritized and measured, and then proposed items for an effective revitalization strategy. Alternatives were evaluated for the types of waterfront that could increase the probability of success of the revitalization process. The proposed methodology can be used in the context of sustainability. As it works to strengthen the city's identity, increase opportunities for conservation, economic and social development, and improve the quality of life. As well as increasing the awareness of the community, beneficiaries, and stakeholders of the place and increasing sympathy with heritage, conservation, culture and landscapes to support decision-making. Finally, looking at similar cases for other cities, it is possible to follow such an analytical approach presented in this study. Various other criteria can also be combined depending on the changing conditions of cities.

\section{REFERENCES}

[1] Ragheb, A.A., EL-Ashmawy, R.A. (2020). Urban waterfront development for designing space in coastal cities. International Journal of Sustainable Development and Planning, 15(3): 345-352. https://doi.org/10.18280/IJSDP.150311

[2] Breen, A., Rigby, D. (1996). The new waterfront: A worldwide urban success story. London: Thames and Hudson, 5-9.

[3] Wong, T.C. (2006). Revitalising Singapore's central city through gentrification: The role of waterfront housing. Urban Policy and Research, 24(2): 181-199. https://doi.org/10.1080/08111140600703808
[4] Niemann, B., Weber, S. (2013). The particular case of urban waterfronts. WIT Transactions on Ecology and the Environment, 179 : https://doi.org/10.2495/SC130471

[5] Oakley, S. (2007). The role of urban governance in reconstructing place, economic function and social relations in urban waterfront regeneration: The case of Port Adelaide, South Australia. Space and Polity, 11(3): 279-295. https://doi.org/10.1080/13562570701811585

[6] Sairinen, R., Kumpulainen, S., (2006). Assessing social impacts in urban waterfront regeneration. Environmental Impact Assessment Review, 26(1): 120-135. https://doi.org/10.1016/J.EIAR.2005.05.003

[7] Ragheb, G., Ragheb, A.A., Ragheb, R.A. (2017). Adaptive re-use and sustainable development for existing historic buildings-case study: Buildings of racetrack horses in sporting club, Alexandria, Egypt. International Journal of Current Engineering and Technology, 7(4): 1523-1530.

[8] Da, T., Xu, Y. (2016). Evaluation on connectivity of urban waterfront redevelopment under hesitant fuzzy linguistic environment. Ocean \& Coastal Management, 132: 101-110. https://doi.org/10.1016/j.ocecoaman.2016.08.014

[9] Girard, L.F., Kourtit, K., Nijkamp, P. (2014). Waterfront areas as hotspots of sustainable and creative development of cities. Sustainability, 6(7): 4580-4586. https://doi.org/10.3390/SU6074580

[10] Kostopoulou, S. (2013). On the revitalized waterfront: Creative milieu for creative tourism. Sustainability, 5(11): 4578-4593. https://doi.org/10.3390/SU5114578

[11] Rössler, M. (2006). World heritage cultural landscapes: a UNESCO flagship programme 1992-2006. Landscape Research, 31(4): 333-353. https://doi.org/10.1080/01426390601004210

[12] Donofrio, J.T. (2007). Preservation as a tool for waterfront revitalization: Design, management, and financing solutions from Vancouver, Boston, and London. Theses (Historic Preservation). University of Pennsylvania.

[13] Ragheb, G.A. (2021). Multi-criteria decision making of sustainable adaptive reuse of heritage buildings based on the A'WOT analysis: A case study of cordahi complex, Alexandria, Egypt. International Journal of Sustainable Development and Planning, 16(3): 485-495. https://doi.org/10.18280/ijsdp.160309

[14] Eldeeb, S.S., Galil, R.A., Sarhan, A.E. (2015). A sustainability assessment framework for waterfront communities. Renewable Energy and Sustainable Development, $\quad 1(1)$ : $167-183$. https://doi.org/10.21622/RESD.2015.01.1.167

[15] Giovinazzi, O., Moretti, M. (2010). Port cities and urban waterfront: Transformations and opportunities. TeMA: Journal of Land Use, Mobility and Environment, 2. https://doi.org/10.6092/1970-9870/123

[16] Keyvanfar, A., Shafaghat, A., Mohamad, S., Abdullahi, M.M., Ahmad, H., Derus, N.H.M. (2018). A sustainable historicwaterfront revitalization decision support tool for attracting tourists. Sustainability (Switzerland), 10(2). https://doi.org/10.3390/SU10020215

[17] Sharma, M.J., Moon, I., Bae, H. (2008). Analytic hierarchy process to assess and optimize distribution network. Applied Mathematics and Computation, 256265. https://doi.org/10.1016/j.amc.2008.02.008 
[18] Saaty, T.L., Vargas, L.G. (2013). Decision Making with the Analytic Network Process. vol. 195, Boston, MA: Springer US.

[19] Görener, A., Toker, K., Uluçay, K. (2012). Application of combined SWOT and AHP: A case study for a manufacturing firm. Procedia - Social and Behavioral Sciences, $\quad 58$ : 1525-1534 https://doi.org/10.1016/j.sbspro.2012.09.1139

[20] Saaty, T.L. (2008). Decision making with the analytic hierarchy process. International Journal of Services Sciences, $1(1)$ : 83-98. https://doi.org/10.1504/IJSSCI.2008.017590

[21] Dabouh, I.Z., El Shazly, M. (2020). Analytic Hierarchy Process in Decision Making Of Heritage Reuse: Sursock Pasha. vol. 67.

[22] Mah, A. (2014). Port Cities and Global Legacies. 1st ed., Licensed to University of Warwick - Palgrave Macmillan.

[23] Gani, A.A., Awang, K.W., Samdin, Z., Mohd, A. (2012). Local community participation in sustainable tourism planning of Malaysian protected areas. Current Issues in Hospitality and Tourism Research and Innovations Proceedings of the International Hospitality and Tourism Conference, IHTC 2012, 459-464. https://doi.org/10.1201/B12752-90

[24] El-Shimy, H., Ragheb, G.A., Ragheb, A.A. (2015). Using mixed reality as a simulation tool in urban planning project for sustainable development. Journal of Civil Engineering and Architecture, 9: 830-835, https://doi.org/10.17265/1934-7359/2015.07.009

[25] Malpas, J. (2008). New media, cultural heritage and the sense of place: Mapping the conceptual ground. International Journal of Heritage Studies, 14(3): 197-209. https://doi.org/10.1080/13527250801953652

[26] Hartig, J.H., Bennion, D. (2017). Historical loss and current rehabilitation of shoreline habitat along an urbanindustrial River-Detroit River, Michigan, USA. Sustainability (Switzerland), 9(5). https://doi.org/10.3390/SU9050828

[27] Epa, O.U. (2015). Why are wetlands important. Environmental Science.

[28] Nelson, A. (2019). A suite of global accessibility indicators. Scientific Data, 6(1). https://doi.org/10.1038/S41597-019-0265-5

[29] Shaziman, S., Usman, I.M.S. (2010). Waterfront as public space case study; klang river between masjid jamek and central market, Kuala Lumpur. Selected Topics in Energy, Environment, Sustainable Development and Landscaping, WSEAS Pres, 344-349.

[30] Lamit, H.B., Shafaghat, A., Majid, M.Z.A., Keyvanfar, A., Ahmad, M.H. Bin., Malik, T.A. (2013). The Path Walkability Index (PAWDEX) model: To measure built environment variables influencing residents' walking behavior. Advanced Science Letters, 19(10): 3017-3020. https://doi.org/10.1166/ASL.2013.5066

[31] Balsas, C.J.L. (2014). Downtown resilience: A review of recent (re)developments in Tempe, Arizona. Cities, 36: 158-169. https://doi.org/10.1016/J.CITIES.2012.10.002

[32] Belniak, S. (2008). A partnership of public and private sectors as a model for the implementation of urban revitalization projects. Journal of European Real Estate Research, $1(2)$ : 139-150. https://doi.org/10.1108/17539260810918712

[33] Elnabwy, M.T., Elbeltagi, E., El Banna, M.M., Elshikh, M.M., Motawa, I., Kaloop, M.R. (2020). An approach based on Landsat images for shoreline monitoring to support integrated coastal management - a case study, Ezbet Elborg, Nile Delta, Egypt. ISPRS International Journal of Geo-Information, 9(4): 199. https://doi.org/10.3390/IJGI9040199

[34] Ewing, A.F. (1970). Egypt, the Crucible - the unfinished revolution of the Arab world by Harry Hopkibs London, Secker and Warburg, 1969. Pp. xxiv+ 533. 100s. The Journal of Modern African Studies, 8(3): 488-490. https://doi.org/10.1017/S0022278X00020048

[35] Khoury, P.S., Philipp, T. (1986). The Syrians in Egypt, 1725-1975. The American Historical Review, 91(3): 713. https://doi.org/10.2307/1869255

[36] Abaza, J. (2015). The 'forgotten' fishermen of Ezbet ElBorg - Daily News Egypt. Daily News Egypt. https://dailynewsegypt.com/2015/04/14/the-forgottenfishermen-of-ezbet-el-borg/.

[37] Albayrak, E., Erensal, Y.C. (2004). Using analytic hierarchy process (AHP) to improve human performance: An application of multiple criteria decision making problem. Journal of Intelligent Manufacturing, 491-503. https://doi.org/10.1023/B:JIMS.0000034112.00652.4c

[38] Kangas, J., Pesonen, M., Kurttila, M., Kajanus, M. (2001). A'WOT: Integrating the AHP with SWOT analysis. 6th ISAHP. Berne, Switzerland, 189-198.

[39] Kurttila, M., Pesonen, M., Kangas, J., Kajanus, M. (2000). Utilizing the analytic hierarchy process (AHP) in SWOT analysis - A hybrid method and its application to a forest-certification case. Forest Policy and Economics, 41-52. https://doi.org/10.1016/s1389-9341(99)00004-0

[40] Weihrich, H. (1982). The TOWS matrix-A tool for situational analysis. Long Range Planning, 15(2): 54-66. https://doi.org/10.1016/0024-6301(82)90120-0

[41] Kajanus, M., Kangas, J., Kurttila, M. (2004). The use of value focused thinking and the A'WOT hybrid method in tourism management. Tourism Management, 25(4): 499506. https://doi.org/10.1016/S0261-5177(03)00120-1

[42] Watróbski, J., Ziemba, P., Jankowski, J., Ziolo, M. (2016). Green energy for a green city-A multiperspective model approach. Sustainability (Switzerland), 8(8). https://doi.org/10.3390/SU8080702

[43] Saaty, T.L., n.d. Saaty, T.L. (1980) The Analytic Hierarchy Process Planning, Priority Setting, Resource Allocation. McGraw-Hill, New York, 437. - References - Scientific Research Publishing. https://doi.org/10.21236/ADA214804.

[44] Simon, D. (2008). Urban environments: Issues on the peri-urban fringe. Annual Review of Environment and Resources, 33: 167-185. https://doi.org/10.1146/ANNUREV.ENVIRON.33.0214 07.093240

[45] Odu, G.O. (2019). Weighting methods for multi-criteria decision making technique. Journal of Applied Sciences and Environmental Management, 23(8): 1449-1457. https://doi.org/10.4314/jasem.v23i8.7

[46] Rodwell, D. (2011). Planning systems: Do they fit the current needs of Historic Port Cities? On the Waterfront: Culture, Heritage and Regeneration of Port Cities, BT Convention Centre, Kings Waterfront: Liverpool, UK.

[47] Pendlebury, J., Short, M., While, A. (2009). Urban World Heritage Sites and the problem of authenticity. Cities, 26(6): 349-358. https://doi.org/10.1016/J.CITIES.2009.09.003

[48] Salamone, F.A. (1997). Authenticity in tourism: The San 
angel inns. Annals of Tourism Research, 24(2): 305-321. https://doi.org/10.1016/S0160-7383(97)80003-5

[49] Portman, M.E., Jin, D., Thunberg, E. (2009). Waterfront land use change and marine resource conditions: The case of New Bedford and Fairhaven, Massachusetts. Ecological Economics, 68(8-9): 2354-2362.
https://doi.org/10.1016/J.ECOLECON.2009.03.016

[50] Al-hagla, K.S. (2010). Sustainable urban development in historical areas using the tourist trail approach: A case study of the Cultural Heritage and Urban Development (CHUD) project in Saida, Lebanon. Cities, 27(4): 234248. https://doi.org/10.1016/J.CITIES.2010.02.001 